\title{
HOUSING PRICE DIFFUSION PATTERN OF AUSTRALIA'S STATE CAPITAL CITIES
}

\author{
Zhen Qiang LUO ${ }^{1}$, Chunlu LIU ${ }^{2}$ and David PICKEN ${ }^{3}$ \\ 1 School of Architecture and Building, Deakin University, Waterfront Campus, 1 Gheringhap \\ Street, Geelong, Vic 3217, Australia \\ 2 School of Architecture and Building, Deakin University, Waterfront Campus, 1 Gheringhap \\ Street, Geelong, Vic 3217, Australia \\ Tel.: + 61-3-52278306; Fax: + 61-3-52278303; E-mail: chunlu@deakin.edu.au \\ 3 School of Architecture and Building, Deakin University, Waterfront Campus, 1 Gheringhap \\ Street, Geelong, Vic 3217, Australia
}

Received 29 June 2007; accepted 9 November 2007

\begin{abstract}
The ripple effect of house prices within metropolitan areas has recently been recognised by researchers. However, it is very difficult to formulate and measure this effect using conventional house price theories particularly in consideration of the spatial locations of cities. Based on econometrics principles of the cointegration test and the error correction model, this research develops an innovative approach to quantitatively examine the diffusion patterns of house prices in mega-cities of a country. Taking Australia's eight capital cities as an example, the proposed approach is validated in terms of an empirical study. The results show that a 1-1-2-4 diffusion pattern exists within these cities. Sydney is on the top tier with Melbourne in the second; Perth and Adelaide are in the third level and the other four cities lie on the bottom. This research may be applied to predict the regional housing market behavior in a country.
\end{abstract}

KEYWORD: Ripple effect; House price diffusion; Regional house prices; Cointegration

\section{INTRODUCTION}

House prices in Australian main metropolitan areas displayed sharp increase trends from 1996, until 2004 when the trends eased. Although the current Australian house prices movement does not exhibit any obvious recessionary signs, the housing market in the subnational level such as Sydney is taking the lead in experiencing a downturn after 2004. The evidence from recent research supports the suggestion that house prices shock in one area is likely to be felt in other areas (Alexander and Barrow, 1994, Ashworth and Parker, 1997,
Cook, 2005, MacDonald and Taylor, 1993, Meen, G., 1999, Pollakowski and Ray, 1997, Stevenson, 2004, Tu, 2000). This is the socalled house price diffusion or ripple effect. The ripple effect or house price diffusion in the UK regional house prices has been mentioned frequently in recent literature, such as Alexander and Barrow (1994), Ashworth and Parker (1997), and Pollakowski and Ray (1997). These studies described how the house prices rose first in the South East and gradually spread out over the rest of the UK. Similarly, the recession in the Sydney housing market has potential to influence other markets after the lat-

International Journal of Strategic Property Management

ISSN 1648-715X print / ISSN 1648-9179 online (c) 2007 Vilnius Gediminas Technical University http://www.ijspm.vgtu.lt 
est housing price fall. It also involves several further issues, including the spatial pattern of house prices diffusion, the degree of influence and the length of time that the influence prevails.

The mutual influences between Australian subnational housing markets were described in previous research. Yates (2002) analysed the household incomes and home ownership rates in metropolitan and non-metropolitan areas in every Australian state and territory from 1986 to 1996. It was noted that house prices in the regions with a higher incidence of income polarisation were more likely to increase at a greater rate. This caused low income households to seek home ownership in non-metropolitan areas. Home ownership rates in metropolitan areas dropped more quickly than non-metropolitan areas from 1986 to 1996. In the aggregate Australian housing market, home ownership rate increased only in Darwin but dropped in the other seven states. In terms of regions with high residential densities and rapid immigration, geographic factors were significant in housing price inflation (Berry and Dalton, 2004). At the subnational level, such as the Melbourne housing market, housing affordability was unbalanced between inner suburbs and outer suburbs during the decade of the 1990s (Burke and Hayward, 2001). Housing price in inner suburbs experienced a huge increase but decreased in outer suburbs. Housing policy (or government housing interventions) was also found to influence significantly regional housing markets in Australia. Findings in studies on the NSW northern tablelands showed that government housing interventions were the significant lever of regional development (Medhurst et al., 2002). Maher (1994) analysed the dispersion of median house prices in Australian major cities. The results suggested that the markets exhibited to some extent the equilibrium in house prices diffusion. Bourassa and Hendershott (1995) estimated the divergence of real house prices in six Australian major cities from 1979 to 1993 . The study paid more attention to the influence of some factors on house prices such as wages and population, rather than the interregional influence. However, the studies noted above which focused on the Australian housing market, did not involve examining the interregional induction between markets. Even though Maher mentioned the evidence of regional house price diffusion, he did not go further to analyse the data statistically. The judgment he made was simply from the price trend in the figures. Only Tu (2000) modelled the dynamics of the Australian housing market at both the national and subnational level, and demonstrated two house prices diffusion paths: from Brisbane to Sydney then to Melbourne, or from Brisbane to national then to Melbourne. The study indicated that the Brisbane housing market was the first disseminator to this diffusion pattern. However, the issue of convergence/divergence in regional house prices was not addressed in the study.

The actual house prices are quite different in some regions over time. The question raised here is whether the disparities in house prices occur irregularly or whether there is a lever of adjustment to equilibrium within regional housing markets in the long-run. This issue is always described as convergence or divergence in regional house prices in the existing literature. Alexander and Barrow (1994) asserted that regional house prices were not considered by economic theory to share a common trend over time. The immobility of housing means it cannot be circulated around the country like common goods and therefore divergence in housing prices should be certain. However, the migration of households owing to the economic changes within regions caused the possibility of convergence in regional house prices. Cook (2003) asserted that the convergence explained the ratio that regional house prices return to an equilibrium rather than the disparities in actual prices. Meen (1999) believed that con- 
vergence existed if long run equilibrium relationships occur between the regional housing markets. Using the Kalman filter with parameters' time varying parameter, Cook (2003) examined the convergence of regional house prices in the UK. The results indicate that the regions in the South East proceeded rapidly to convergence in prices recession terms and other regions also converged when the prices were increasing. However, Drake (1995) found evidence detecting divergence with respect to house prices in the North and Scotland but convergence in other some regions.

This paper investigates the long run equilibrium relationship between Australian subnational housing markets to display the house prices diffusion pattern, and addresses the issue of convergence/divergence in Australian regional housing markets. The paper is set out as follows: Section 2 introduces the main techniques used in this paper including the cointegration test and the error correction model. Section 3 describes the data source and the investigation period with respect to the house price index of eight capital cities in Australia. Section 4 tests the stationarity of the data series. Section 5 presents the results of the cointegration test and an illustration of the house price diffusion pattern. The last section provides a concluding discussion.

\section{METHODOLOGIES}

The analysis of causalities among variables is very common in academic research. The causalities among regional housing markets are estimated by statistical or econometric techniques in existing literature, such as the cross correlation matrices, the unit root test, the cointegration test, the vector autoregression model, and the Granger causality test. These causal links between or within regional markets are in fact the spatial house prices diffusion patterns. On the other hand, convergence exists in house prices if the long-run equilibrium relationships occur between the regional housing markets and can be detected by a cointegration test. To find out the long-run equilibrium relationship and determine the casual links amongst Australian regional housing market, two main econometric techniques employed in this study are the unit root test and the Engle-Granger cointegration test. To apply these, two consecutive procedures were carried out as described below.

\subsection{Principle of testing the stationarity}

In this step, the unit root test is used to test the variables' stationarity and the order of integration. If these variables are nonstationary and have the same order of integration, they can be constructed into a cointegration model. The Dicky-Fuller unit root test (DF), the Augmented Dicky-Fuller unit root test (ADF) (Dicky and Fuller, 1979) and the Phillips-Perron unit root test (PP) (Phillips and Perron, 1988) are often used to test stationarity. The ADF and PP tests were used in this study. There are 3 forms of the ADF and PP unit root test model, namely no intercept and trend, intercept but no trend, and intercept and a trend.

\subsection{Engle-Granger cointegration test}

The theory of cointegration was developed by Granger (1981). The Engle-Granger cointegration test is used to determine the pairwise cointegration relationships between variables. Once the two variables are tested to be nonstationary and the orders of integration are tested to be the same order, the EG test (Engle and Granger, 1987) can be used to test the cointegration relationship between each pair of variables. The cointegration regression can rule out the possibility of a spurious regression. Granger (1986) demonstrated that the cointegration is evidence of causality. If the 
cointegration relationship is found, the causal relationship can be detected by the cointegration equation. There are two types of EG test regression: with trend and without trend,

$$
\begin{aligned}
& Y_{t}=\hat{Y}_{t}+e_{t}=\hat{\alpha}_{0}+\hat{\alpha}_{1} X_{t}+e_{t} ; \\
& Y_{t}=\hat{Y}_{t}+e_{t}=\hat{\alpha}_{0}+\beta t+\hat{\alpha}_{1} X_{t}+e_{t} .
\end{aligned}
$$

The product of $\beta$ and $t$ is a time trend. After the OLS regression of $Y$ on $X$, the residual series is made as,

$$
e_{t}=Y-\hat{Y}_{t} .
$$

Using the unit root test to test the stationarity of $e_{t}$, if $e_{t}$ is stationary, $Y_{t}$ and $X_{t}$ are cointegrated. In the application of the Engle-Granger cointegration test first regress $Y$ on $X$ shown as Eqs. (1) or (2). Then the residuals series is generated from the regression shown as $E q$. (3). A stationary residual series will determine a cointegration relationship between $Y$ and $X$. This also called the twostage cointegration test.

\subsection{Error correction model}

The equilibrium relationship does not always occur between variables when the two variables are cointegrated. In the short run, there may be disequilibrium. In fact, the socalled "equilibrium error" sustains the equilibrium relationship in the long run. This error term was first used by Sargan (1984), and is called the "error correction mechanism". The error correction mechanism was developed by Davidson, Hendry, Srba and Yeo (1978) and later popularised by Engle and Granger (1987). If cointegration relationships exist within variables, then the direction of the causality within the variables can be identified by the error correction model as suggested by the Granger
Representation Theorem. In a two I(1) variables model, the error correction model is made as

$$
\begin{aligned}
& \Delta Y_{t}=\beta_{0}+\beta_{1} \Delta X_{t}-\lambda e c m_{t-1}+\mu_{t}, \\
& \text { without a deterministic trend } \\
& \Delta Y_{t}=\beta_{0}+\beta_{1} \Delta X_{t}-\lambda e c m_{t-1}+@ \text { trend }+\mu_{t}, \\
& \text { with a deterministic trend }
\end{aligned}
$$

where: $\Delta Y_{t}$ and $\Delta X_{t}$ denotes time series $Y_{t}$ and $X_{t}$ at first difference level respectively; $Y_{t}$ and $X_{t}$ are assumed to be integrated at first difference in this model; $\beta_{1}$ is the shortrun elasticity; $\lambda$ is the speed of adjustment to equilibrium; "ecm th $_{t-1}$ is the error correction term and $e c m_{t-1}=\left(Y_{t-1}-\alpha_{1}-\alpha_{2} X_{t-1}\right)$, where $\alpha_{2}$ is the long-run elasticity; " @ trend" denotes a deterministic trend; $\mu_{t}$ is the residual error term of this error correction model; The error correction term ecm $e_{t-1}$ is calculated as the residuals obtained from cointegration regression (see $E q$. (3)).

\subsection{Johansen cointegration test}

A multivariate cointegration test is used to detect the long run equilibrium relationship between a set of variables. Johansen (1988) and Stock and Watson (1988) first presented two methods to this issue. The two methods are similar and both based on the vector autoregression model. Johansen cointegration test is employed in this study. To carry out the Johansen cointegration test, a vector autoregression model should be formulated first. The order of the model must be determined which will be shown in next step. The condition of the test is strictly the same as in EG test. All variables should be nonstationary and integrated in the same order. The Johansen cointegration test in Eviews, an econometric computer program, is based on five deterministic trend assumptions involving data trends and test type. In practice, the selection 
of five deterministic trend assumptions is very difficult and complex. The lags interval is also difficult to determine before the selection of the models. However, it is more convenient than the Engle-Granger approach when it is used to test the cointegration relations within more than two variables.

\section{DATA DESCRIPTION}

The study focuses house prices diffusion on subnational level. The data of eight capital cities' house price indices were collected from the publications of Australian Bureau of Statistics (2006). The catalogue number is 6410.0. The observed period was from the December quarter 1989 to the June quarter 2005. The quarterly indices are based on the newly established house prices and each capital city's house price index is calculated on the reference base that the value in 1989-90 is indexed to 100 . The house price indices used in this study measure the pure house price inflation, that is, the price inflation is not concerned with 'any change to either the quantity or the quality of goods or services' (Australian Bureau of Statistics, 2006). Each of the eight indices measures the house price movements over time in each capital cities individually. The indices do not measure the difference in prices between cities. Figure 1 shows the house price movements in eight capital cities. The biggest change rate of house price was in Brisbane $(+310.9 \%)$ during the investigated period, followed by Darwin $(+290.5 \%)$ and Sydney (260.9\%). The Darwin housing market shows a very different behaviour from the other seven markets. Except Darwin, the other seven show

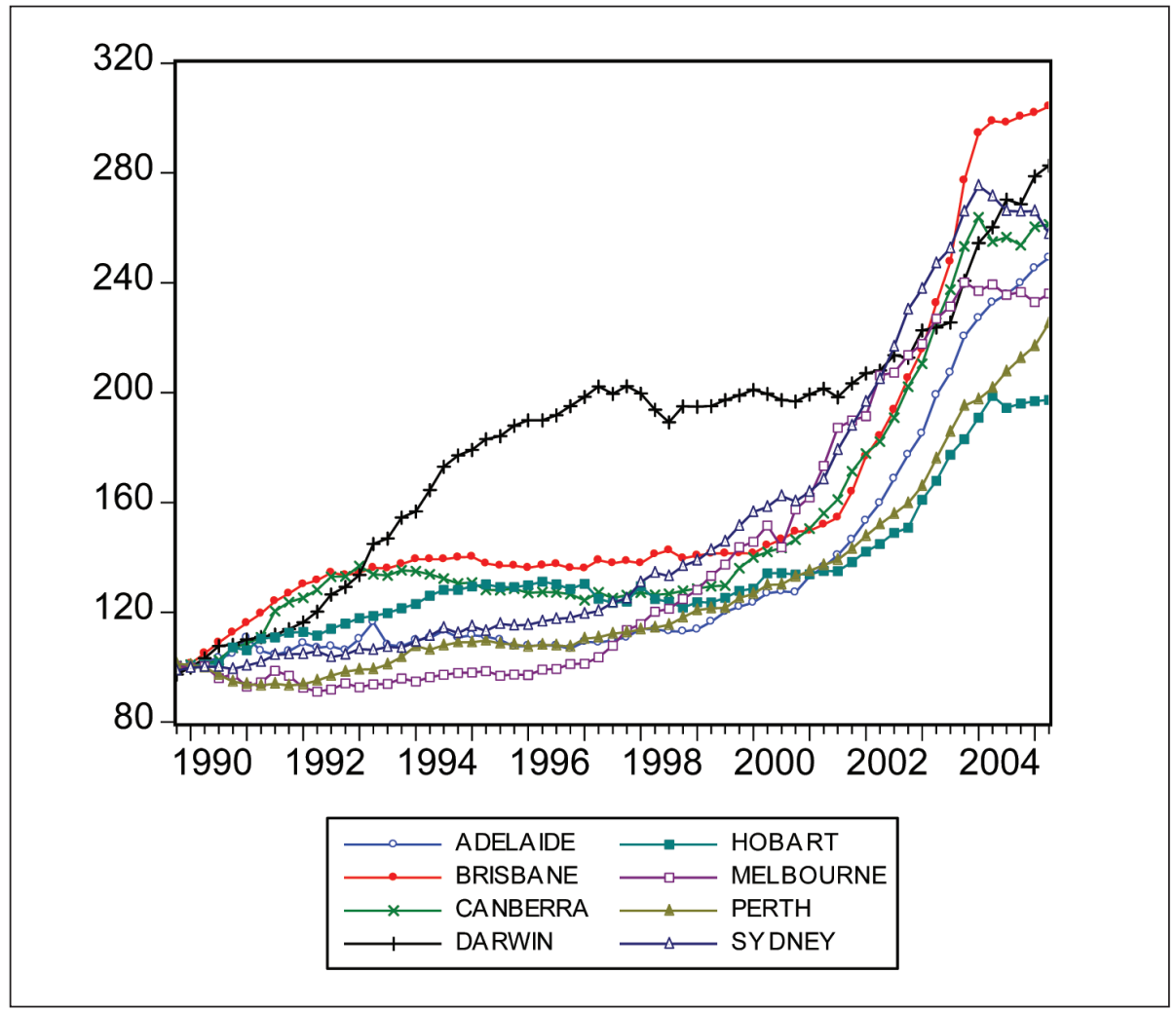

Figure 1. Australian eight capital cities house price indices 
a similar propensity during the investigated period. They all have a slow increase trend first followed by a sharp increase. The start of the latest boom in Melbourne, Adelaide, Perth and Sydney led the other markets. Melbourne's boom started in the December quarter 1996 while the booms in Adelaide, Perth and Sydney started in the March quarter 1997, followed by Brisbane (June quarter 2002), Canberra (June quarter 2000) and Hobart (June quarter 2000). Darwin started its first sharp increase from the December quarter 1989 until the June quarter 1997, with an average change rate of $3.62 \%$ per quarter followed by a steady increase until the September quarter 2000. The latest sharp increase in Darwin started from the December quarter 2001. Melbourne, Sydney, Brisbane, Canberra, and Hobart all had an obvious hesitation in the December quarter 2003 and the March quarter 2004. However, Perth, Darwin ignored this strike and were experiencing their rapid increases. In the tables and figures, the March quarter, June quarter, September quarter and December quarter are denoted as Q1, Q2, Q3 and Q4 respectively.

\section{TESTING STATIONARITY}

The methodology employed in this study involves several procedures. The first procedure is to test whether the data series is stationary. A stationary time series process has a stable probability distribution over time. Its mean and variance are constant, or the value of covariance between two time periods is affected by the lag rather than the time. The stationary process plays an important role in time series analysis. If a time series is nonstationary, its behavior can only be studied in a particular time period. To other time periods, it is difficult to generalise valuable information from its behaviour. Another problem is the regression of nonstationary time series would lead to a phenomenon of spurious regression. For example, Granger and Newbold (1974) showed there was a significant statistical relationship between two uncorrelated nonstationary series. To avoid the problems shown above, the unit root test was used to test the stationarity and the order of integration.

Table 1 shows the unit root test results of eight capital cities, using the Augmented Dicky-Fuller unit root test and the PhillipsPerron unit root test. The ADF test approach was introduced by Dicky and Fuller (1979) and the PP test by Phillips and Perron (1988). The null hypothesis of nonstationary was performed at the $1 \%$ and $5 \%$ significance levels. There are three different null hypotheses of the time series processes in this test: process as a random walk, process as a random walk with drift, and process as a random walk with drift around a deterministic trend. They are shown in Table 1 respectively: no trend and intercept, intercept without trend and, intercept and trend. The results shows that eight capital cities house price index data series are not stationary at the level form but stationary after the first difference at the $1 \%$ and $5 \%$ significance levels. That is, all the eight data series are I(1) which denotes that the time series is integrated at the first difference level.

\section{LONG RUN EQUILIBRIUMS BETWEEN SUBNATIONAL HOUSING MARKETS}

\subsection{Pairwise cointegration relationship}

The cointegration test was employed to detect the long run equilibrium relationships between Australian regional house prices in order to reveal the causal relationships between regional housing markets. Two variables are said to be cointegrated if they share a common trend or tie together in a long run equilibrium relationship. The Engle-Granger test 
first regresses one regional house price index on another one and obtains a least squares regression. Then a unit root test is performed on the residuals obtained from the least squares regression to test the stationarity (see $E q$. (3)). If the series of the residuals is stationary, the two regional house prices are said to be cointegrated; that is, they share a common trend in the long term. In addition, the regression is not considered as spurious. There are two types of cointegrating regression models in this test: without trend and with trend. They were formulated as Eqs. (1) and (2).
Table 2 shows the pairwise cointegration test results of eight capital cities house price indices, based on the cointegrating regression without trend. The critical $t$ values are $2.605442,1.946549$ and 1.613181 at the $1 \%$, $5 \%$ and $10 \%$ respectively. The 56 numbered cells denote the least squares regression equations and unit root tests (tested by the $\mathrm{ADF}$ ) on residuals obtained from each regression equation. Each of the numbers with asterisks denotes the series of residuals obtained from the individual regression equation is stationary; that is, the two variables in this regres-

Table 1. Eight capital cities house price index series unit root test (1989 Q4 to 2005 Q2)

\begin{tabular}{|c|c|c|c|c|c|c|c|c|c|c|}
\hline & & \multicolumn{3}{|c|}{ ADF test at levels } & \multicolumn{3}{|c|}{ ADF test in first difference } & \multicolumn{3}{|c|}{ PP test in first difference } \\
\hline & & t-statistic & $\begin{array}{l}\text { Sig. } \\
\text { level }\end{array}$ & lag & t-statistic & $\begin{array}{l}\text { Sig. } \\
\text { level }\end{array}$ & lag & t-statistic & $\begin{array}{l}\text { Sig. } \\
\text { level }\end{array}$ & lag \\
\hline \multirow{8}{*}{ 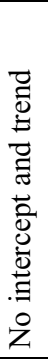 } & Adelaide & 2.0278 & na & 2 & -1.2669 & na & 2 & -3.2759 & $* * *$ & 4 \\
\hline & Brisbane & 1.3589 & na & 1 & -2.3787 & $* *$ & 0 & -2.2842 & $* *$ & 3 \\
\hline & Canberra & 1.5795 & na & 2 & -2.2184 & $* *$ & 1 & -3.4396 & $* * *$ & 3 \\
\hline & Darwin & 5.7461 & na & 0 & -1.6504 & na & 2 & -4.8125 & $* * *$ & 5 \\
\hline & Hobart & 1.7465 & na & 2 & -2.6173 & $* * *$ & 1 & -5.0631 & $* * *$ & 4 \\
\hline & Melbourne & 1.8664 & na & 2 & -2.5472 & $* *$ & 1 & -6.3695 & $* * *$ & 5 \\
\hline & Perth & 2.7436 & na & 1 & -0.9251 & na & 1 & -1.1558 & na & 7 \\
\hline & Sydney & 1.2754 & na & 1 & -2.7638 & $* *$ & 0 & -2.4459 & $* *$ & 3 \\
\hline \multirow{5}{*}{ 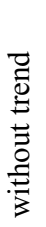 } & Adelaide & 2.8336 & na & 2 & -2.5365 & na & 1 & -4.3519 & $* * *$ & 4 \\
\hline & Brisbane & 0.1168 & na & 1 & -2.7776 & na & 0 & -2.7824 & na & 2 \\
\hline & Canberra & 0.1609 & na & 2 & -2.7632 & na & 1 & -4.2487 & $* * *$ & 3 \\
\hline & Darwin & 0.5418 & na & 0 & -3.4701 & $* *$ & 1 & -6.4004 & $* * *$ & 4 \\
\hline & Hobart & 0.1460 & na & 2 & -3.1872 & $* *$ & 1 & -5.9866 & $* * *$ & 4 \\
\hline \multirow{3}{*}{ 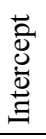 } & Melbourne & 0.5446 & na & 2 & -3.1566 & $* *$ & 1 & -7.2580 & $* * *$ & 4 \\
\hline & Perth & 3.5867 & na & 1 & -2.4795 & na & 0 & -2.0687 & na & 4 \\
\hline & Sydney & -0.2029 & na & 1 & 3.1482 & $* *$ & 0 & -2.9802 & $* *$ & 1 \\
\hline \multirow{5}{*}{ 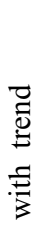 } & Adelaide & 1.7206 & na & 0 & -5.6193 & $* * *$ & 0 & -5.8555 & $* * *$ & 4 \\
\hline & Brisbane & -1.1555 & na & 1 & -3.0512 & na & 0 & -3.0916 & na & 2 \\
\hline & Canberra & -2.7931 & na & 1 & -4.5554 & $* * *$ & 0 & -4.6277 & $* * *$ & 3 \\
\hline & Darwin & -1.7549 & na & 3 & -3.4889 & $* *$ & 1 & -6.3998 & $* * *$ & 4 \\
\hline & Hobart & -1.1298 & na & 2 & -5.9530 & $* * *$ & 0 & -6.2442 & $* * *$ & 4 \\
\hline \multirow{3}{*}{ 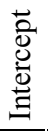 } & Melbourne & -1.8461 & na & 0 & -3.6141 & $* *$ & 1 & -8.0854 & $* * *$ & 4 \\
\hline & Perth & 1.3266 & na & 1 & -4.5236 & $* * *$ & 0 & -4.5236 & $* * *$ & 0 \\
\hline & Sydney & -3.3321 & na & 4 & -3.1203 & na & 0 & -3.1203 & na & 0 \\
\hline
\end{tabular}

Note: $* *$ and $* * *$ denote the rejection of null hypothesis at the $5 \%$ and $1 \%$ significance level respectively. 
sion are cointegrated. The results show that there are 14 pairs of regional house price indices are cointegrated. Each pair has a long run equilibrium relationship.

Table 3 shows the pairwise cointegration test results of eight capital cities house price indices, based on the cointegrating regression with a time trend. Table 3 shows 11 pairs of regional house price indices which were tested to be cointegrated. Seven pairs in the 11 have been observed in Table 2. The other four pairs are: Perth and Sydney, Hobart and Sydney, Brisbane and Melbourne, and Adelaide and Perth.

\subsection{Housing price diffusion pattern}

According to Johansen (1988), if cointegration existed, it suggested that causality (in the Granger sense) must exist in at least one direction. The direction is identified by the error correction model shown in Appendix 1. Table 4 shows the summary of error correction model equations of eight markets in which each error correction model equation corresponds to the result of Engle-Granger cointegration regression in Table 2 and Table 3. Only the regression in which the cointegration relation is determined can be expressed as an error correction model. The

Table 2. Augmented Dicky-Fuller statistics on Engle-Granger cointegrating residuals without trend

\begin{tabular}{lcccccccc}
\hline & Adelaide & Brisbane & Canberra & Darwin & Hobart & Melbourne & Perth & \multicolumn{2}{l}{ Sydney } \\
\hline Adelaide & - & $-2.6388^{* * *}$ & $-2.3829^{* *}$ & -1.825399 & $-2.3220^{* *}$ & $-2.1763^{* *}$ & -1.478661 & -1.837402 \\
Brisbane & $-2.4512^{* *}$ & - & $-2.5046^{* *}$ & -1.743393 & $-2.2820^{* *}$ & -1.228036 & $-2.1443^{* *}$ & -1.406054 \\
Canberra & $-2.0996^{* *}$ & $-2.5110^{* *}$ & - & -1.607004 & $-2.0699^{* *}$ & -1.090974 & -1.070704 & -0.580889 \\
Darwin & $-1.9621^{* *}$ & -1.571243 & -1.408529 & - & -0.80757 & -1.599531 & -0.499957 & $-2.2363 * *$ \\
Hobart & -1.913776 & $-2.1343^{* *}$ & $-2.0405^{* *}$ & -1.551317 & - & -1.18937 & $-2.0863^{* *}$ & -1.115505 \\
Melbourne & $-2.3441^{* *}$ & -1.153874 & -0.824378 & -1.699563 & -1.843034 & - & $-3.0965^{* * *}$ & $-2.5088^{* *}$ \\
Perth & -1.569791 & $-2.5500^{* *}$ & -1.588729 & $-2.6699 * * *$ & $-2.5467 * *$ & $-3.1138^{* * *}$ & - & -1.8898 \\
Sydney & -1.500626 & -1.238734 & -1.080267 & -1.816811 & -0.886924 & $-2.5209^{* *}$ & -1.5487 & - \\
\hline
\end{tabular}

Note: $* *$ and $* * *$ denote the rejection of null hypothesis at the $5 \%$ and $1 \%$ significance level respectively

Table 3. Augmented Dicky-Fuller statistics on Engle-Granger cointegration residuals with trend

\begin{tabular}{|c|c|c|c|c|c|c|c|c|}
\hline & Adelaide & Brisbane & Canberra & Darwin & Hobart & Melbourne & Perth & Sydney \\
\hline Adelaide & - & na & $-2.2502 * *$ & na & $-2.0618 * *$ & na & $-2.9937 * * *$ & na \\
\hline Brisbane & na & - & $-2.3814^{* *}$ & -0.954782 & $-2.7869 * * *$ & $-2.1080 * *$ & $-2.9761 * * *$ & na \\
\hline Canberra & na & na & - & na & $-2.0301 * *$ & na & -1.63724 & na \\
\hline Darwin & na & na & na & - & & -1.013382 & na & na \\
\hline Hobart & na & $-2.6654 * * *$ & na & -1.204122 & - & na & $-2.3423 * *$ & $-2.8100 * * *$ \\
\hline Melbourne & $-2.8697 * * *$ & na & na & -0.126473 & -1.663802 & - & na & na \\
\hline Perth & $-3.0050 * * *$ & $-3.2695 * * *$ & -1.944426 & na & na & $-3.0265 * * *$ & - & $-2.5428 * *$ \\
\hline Sydney & -1.468562 & na & -1.025524 & na & na & na & na & - \\
\hline
\end{tabular}

Note: $* *$ and $* * *$ denote the rejection of null hypothesis at the $5 \%$ and $1 \%$ significance level respectively 
symbols $\beta_{1}$ and $\lambda$ in the error correction model correspond to Eqs. (4) and (5), respectively. The symbol $\lambda$ is the short-run elasticity which shows the short-run change rates. The symbol $\beta_{1}$ is the speed of adjustment to disequilibrium which represents the rate of departing from long-run equilibrium to disequilibrium. Totally, 29 error correction model equations are adopted in this research including 5 equations obtained from cointegration regression with trend (see Eq. (5)).

Figure 2 is generated from the results of Table 3 and the error correction model, based on the results of a cointegration regression without trend. It shows the causal relationships between Australian regional housing markets.

Figure 3 is generated from the results of
Table 3, based on the results of cointegration regression with trend. Except five causal relationships in Figure 3 which is not shown in Figure 2, the others have been found in Figure 2 . These five causal relationships are Brisbane Granger causes Melbourne, Hobart Granger causes Sydney, Perth Granger causes Sydney, Adelaide Granger causes Perth and Perth Granger causes Adelaide. It is important to note that the statement " $\mathrm{X}$ Granger causes $Y$ " does not mean that $\mathrm{Y}$ is the effect or result of X. Granger causality measures precedence and information content and does not relate to the meaning of causality in common use.

Figures 2 and 3 show the regional house prices diffusion pattern in Australia. The Darwin housing market does not have as firm a relationship as the others. There are 3 correla-

Table 4. Error correction summary derived from Engel-Granger cointegration regression

\begin{tabular}{|c|c|c|c|c|c|c|c|c|c|}
\hline \multirow[t]{2}{*}{$\Delta \mathrm{X}$} & & \multicolumn{8}{|l|}{$\Delta \mathrm{Y}$} \\
\hline & & Adelaide & Brisbane & Canberra & Darwin & Hobart & Melbourne & Perth & Sydney \\
\hline \multirow[t]{2}{*}{ Adelaide } & $\beta_{1}$ & & 0,92454 & 0,748329 & - & 0,457519 & 0,316987 & 0,228256 & - \\
\hline & $\lambda$ & & $-0,1767$ & $-0,114091$ & - & $-0,11915$ & 0,05001 & $-0,217385$ & - \\
\hline \multirow[t]{2}{*}{ Brisbane } & $\beta_{1}$ & 0,592125 & & 0,590497 & - & 0,353377 & 0,077697 & 0,197337 & - \\
\hline & $\lambda$ & $-0,07136$ & & 0,048743 & - & $-0,155604$ & 0,005289 & $-0,071376$ & - \\
\hline \multirow[t]{2}{*}{ Canberra } & $\beta_{1}$ & $-0,52349$ & 0,785233 & & - & 0,172205 & - & - & - \\
\hline & $\lambda$ & $-0,12135$ & $-0,16566$ & & - & $-0,226244$ & - & - & - \\
\hline \multirow[t]{2}{*}{ Darwin } & $\beta_{1}$ & 0,178691 & - & 0,37917 & & - & - & - & 0,301322 \\
\hline & $\lambda$ & 0,039621 & - & $-0,111247$ & & - & - & - & 0,011978 \\
\hline \multirow[t]{2}{*}{ Hobart } & $\beta_{1}$ & - & 0,814583 & - & - & & - & 0,135804 & 0,278044 \\
\hline & $\lambda$ & - & 0,318391 & - & - & & - & $-0,630636$ & 0,050946 \\
\hline \multirow[t]{2}{*}{ Melbourne } & $\beta_{1}$ & 0,146136 & & - & - & - & & 0,337008 & 0,247951 \\
\hline & $\lambda$ & $-0,06696$ & & - & - & - & & $-0,053628$ & $-0,275755$ \\
\hline \multirow[t]{2}{*}{ Perth } & $\beta_{1}$ & 0,843697 & 0,514525 & - & 0,387599 & 0,59925 & 0,452196 & & $-0,296417$ \\
\hline & $\lambda$ & $-0,11523$ & $-0,0845$ & - & $-0,05735$ & $-0,13201$ & 0,081181 & & 0,191727 \\
\hline \multirow[t]{2}{*}{ Sydney } & $\beta_{1}$ & - & - & - & - & - & 0,523499 & - & \\
\hline & $\lambda$ & - & - & - & - & - & $-0,288406$ & - & \\
\hline
\end{tabular}

Notes: $\beta 1$ denotes short-run elasticity, $\lambda$ denotes speed of adjustment to equilibrium. 


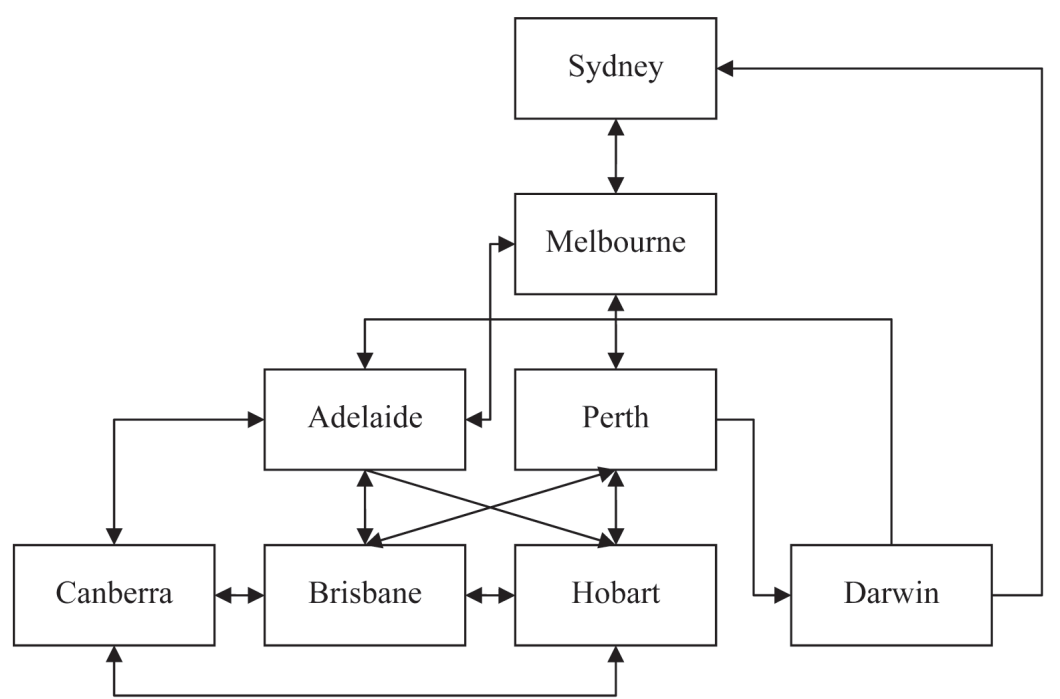

Figure 2. Causal relationships between Australian capital cities based on cointegration regression without trend

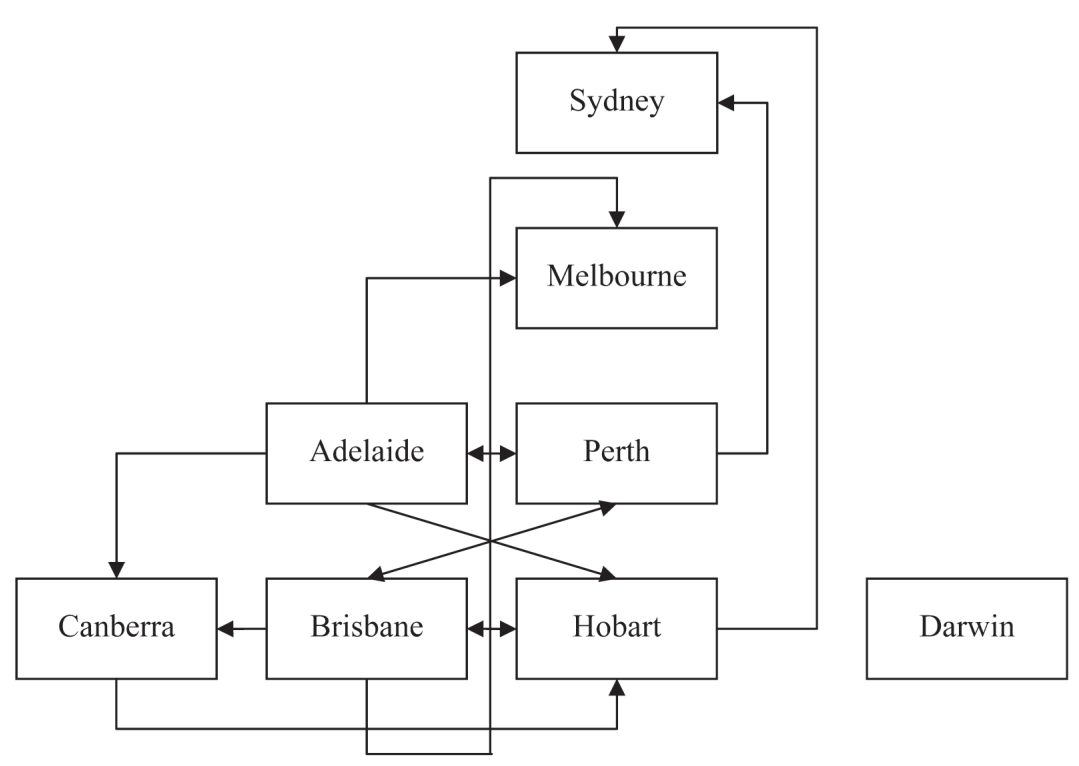

Figure 3. Causal relationships between Australian capital cities based on cointegration regression with trend 
tion coefficients of regression less than 0.75 : regression of Sydney on Darwin $\left(R^{2}=0.695077\right)$, Adelaide on Darwin $\left(R^{2}=0.611663\right)$ and Darwin on Perth $\left(R^{2}=0.731842\right)$. The others are larger than or equal 0.919555, except Melbourne on Adelaide $\left(R^{2}=0.879922\right)$, Adelaide on Melbourne $\left(R^{2}=0.879922\right)$ and Melbourne on Brisbane $\left(R^{2}=0.896859\right)$. The results show that the Darwin housing market seems more independent.

The Sydney housing market, as the most dynamic and biggest one in Australia, does not influence all other markets directly except the Melbourne market. Similar findings were inspected in other studies such as the London market in the UK (Alexander and Barrow, 1994) and the Dublin market in Ireland (Stevenson, 2004). Stevenson (2004) examined the ripple effect taking place in the Republic of Ireland in the period of 1978-2002. The findings showed the Dublin market did not Granger cause other markets directly, but Dublin Granger caused provincial regions via rural areas. This result in Alexander and Barrow (1994) shows that the South East market was shown to be the main driving force in the UK housing market rather than the Greater London market. The findings do not support the suggestion that the biggest housing market is the driving force in an aggregate national housing market.

Besides the Sydney market, Melbourne only influences Adelaide and Perth directly. It affects Canberra, Brisbane, Hobart and Darwin via Adelaide and Perth. In a similar way, Sydney affects Canberra, Brisbane, Hobart and Darwin via Melbourne then to Adelaide and Perth. The results support the proposition that house prices diffusion in Australia displays a ripple effect: Sydney is on the top tier followed by Melbourne in the second tier: Adelaide and Perth in the third tier and the others are at the bottom tier. However, Meen (1999) suggested that the key incentive to the ripple effect is the adjustments within regional hous- ing markets rather than between markets. These adjustments were common across all regions and reflected the variations of economic growth within regions. In the diffusion pattern shown in Figures 2 and 3, it is found that every housing market has at least one regurgitant path through other markets to itself. The results support Meen's notion that every subnational market would play the role of epicentre. This indicates that all regional housing markets would be epicentres of the ripple effect, not just Sydney as had been expected. Meanwhile, three causal relationships are unilateral which could be assumed as a feedback from the lower tiers: Darwin to Sydney, Perth to Sydney and Hobart to Sydney. This also happens with the Melbourne housing market: Brisbane to Melbourne.

The spatial interaction between contiguous or non-contiguous markets is another phenomenon of the ripple effect. The evidences show that the ripple effect does not diffuse exactly through contiguous markets as a real geographical pattern. Some contiguous regional housing markets present causal relationships, such as Melbourne and Adelaide, and Adelaide and Perth. However, there are more causal relationships that were observed between noncontiguous regions, such as the causalities of Perth and Brisbane, and Brisbane and Hobart. In addition, some contiguous regional housing markets do not exhibit the direct causal relationships as expected, such as Sydney and Canberra, and Melbourne and Hobart. The results clearly do not support the notion that regional house prices diffusion is strictly through the contiguous or adjoining region. For policy makers, the causalities within the eight markets are so complicated that housing policy being an influence on the local housing market is not considered in isolation any more. It would involve more complicated situations happening in other regions not only in the real estate market but also in others such as economic growth. 


\subsection{Dispersion in regional housing prices}

The cointegration test has exposed the straightforward interaction between regional housing markets. Table 5 shows the results of the Johansen cointegration test summary. There are 4 time intervals which were selected in the test, including 1 to 1,1 to 2,1 to 3 , and 1 to 4 . The time intervals of 1 to 5 and up cannot be selected in this test due to insufficiency of the data observations. The numbers in Table 5 show the numbers of cointegration relations. Regardless of which time interval is selected, the results show that there are cointegration relationships occurring in house prices in the eight capital cities. This demonstrates that there are some long run equilib- rium relationships in eight capital cities housing markets. The result suggests that Australian regional housing markets share common trends in the long run. According to Cook (2003) the convergence explained the ratio that regional house prices return to a equilibrium within regional housing markets rather than the disparities in actual prices. The Johansen cointegration test results provide evidence of convergence existing between eight capital cities' housing market. In the same way, the pairwise cointegration test results detect convergence occurring in couple pairs of capital cities such as, for example, Melbourne and Sydney, Melbourne and Perth, Melbourne and Adelaide, Perth and Adelaide. To sum up, the dispersion in house prices in Australia's capital cities is not increasing. On the contrary,

Table 5. Multivariable cointegration test (Johansen cointegration test summary)

\begin{tabular}{|c|c|c|c|c|c|}
\hline \multicolumn{6}{|c|}{ Lags interval: 1 to 1} \\
\hline Data Trend: & None & None & Linear & Linear & Quadratic \\
\hline \multirow[t]{2}{*}{ Test Type } & No Intercept & Intercept & Intercept & Intercept & Intercept \\
\hline & No Trend & No Trend & No Trend & Trend & Trend \\
\hline Trace & 4 & 3 & 3 & 3 & 3 \\
\hline Max-Eig & 3 & 3 & 3 & 3 & 3 \\
\hline \multicolumn{6}{|c|}{ Lags interval: 1 to 2} \\
\hline Data Trend: & None & None & Linear & Linear & Quadratic \\
\hline \multirow[t]{2}{*}{ Test Type } & No Intercept & Intercept & Intercept & Intercept & Intercept \\
\hline & No Trend & No Trend & No Trend & Trend & Trend \\
\hline Trace & 5 & 5 & 4 & 5 & 5 \\
\hline Max-Eig & 4 & 4 & 4 & 5 & 3 \\
\hline \multicolumn{6}{|c|}{ Lags interval: 1 to 3} \\
\hline Data Trend: & None & None & Linear & Linear & Quadratic \\
\hline \multirow[t]{2}{*}{ Test Type } & No Intercept & Intercept & Intercept & Intercept & Intercept \\
\hline & No Trend & No Trend & No Trend & Trend & Trend \\
\hline Trace & 6 & 6 & 5 & 6 & 5 \\
\hline Max-Eig & 3 & 3 & 2 & 3 & 2 \\
\hline \multicolumn{6}{|c|}{ Lags interval: 1 to 4} \\
\hline Data Trend: & None & None & Linear & Linear & Quadratic \\
\hline \multirow[t]{2}{*}{ Test Type } & No Intercept & Intercept & Intercept & Intercept & Intercept \\
\hline & No Trend & No Trend & No Trend & Trend & Trend \\
\hline Trace & 6 & 7 & 5 & 6 & 6 \\
\hline Max-Eig & 6 & 6 & 5 & 6 & 6 \\
\hline
\end{tabular}

Notes: Critical values based on MacKinnon-Haug-Michelis (1999) 
the subnational house prices tie together and share the same trend. There should be kinds of equilibrium which reconcile the short term behaviour of house prices with their long term behavior in Australian housing market. That is, there is no housing market where the upward/downward trend is totally isolated from the aggregated Australian housing market.

\section{CONCLUSIONS}

This study focused on several issues in Australian subnational housing markets: ripple effect, contiguous effect, and convergence, which have been examined frequently in recent regional house prices diffusion literature. Using the cointegration test, this paper has examined the house prices diffusion pattern in the Australian eight state capital cities from the December quarter to the June quarter of 2005 . The findings highlight a number of issues which are set out below.

The Engle-Granger cointegration test results display a 1-1-2-4 of four tiers network links which formulates the current Australian subnational house price diffusion pattern: Sydney is on the top tier with Melbourne in the second; Perth and Adelaide are in the third level and the other four cities lie on the bottom. The diffusion pattern shows the linkages with both contiguous areas and noncontiguous areas. Meanwhile, there are three causal relationships which are unilateral and which could be assumed as feedback from the lower tiers: Darwin to Sydney, Perth to Sydney and Hobart to Sydney. This also happens in the Melbourne housing market: Brisbane to Melbourne. The results also uncover the convergence phenomenon existing between pairs of regional markets such as Melbourne and Sydney, Melbourne and Perth, Melbourne and Adelaide. It indicates that each pair of housing markets return to equilibrium with some ratios. In addition, the Johansen cointegration results suggest convergence occurring in the aggregate Australian housing market. It means that the eight capital cities' house prices return to equilibrium with their own ratios.

\section{REFERENCES}

Alexander, C. and Barrow, M. (1994) Seasonality and cointegration of regional house prices in the UK. Urban Studies, 31(10), p. 1667-1689.

Ashworth, J. and Parker, S. C. (1997) Modelling regional house prices in the UK. Scottish Journal of Political Economy, 44(3), p. 225-246.

Australian Bureau of Statistics (2006) Information paper, House Price Indexes: Eight Capital Cities, June 2006, Australian Bureau of Statistics, Canberra.

Berry, M. and Dalton, T. (2004) Housing prices and policy dilemmas: a peculiarly Australian problem? Urban Policy and Research, 22(1), p. 6991.

Bourassa, S. C. and Hendershott, P. H. (1995) Australian capital city real house prices, 1979-1993. The Australian Economic Review, (111), p. 1626.

Burke, T. and Hayward, D. (2001) Melbourne's housing past, housing futures. Urban policy and Research, 19(3), p. 291-310.

Cook, S. (2003) The convergence of regional house prices in the UK. Urban Studies, 40(11), p. 2285-2294.

Cook, S. (2005) Detecting long-run relationships in regional house prices in the UK. International Review of Applied Economics, 19(1), p. 107-118.

Davidson, J. E. H., Hendry, D. F., Srba, F. and Yeo, S. (1978) Econometric modelling of the aggregate time-series relationship between consumers' expenditure and income in the United Kingdom. The Economic Journal, 88(352), p. 661-692.

Dicky, D. A. and Fuller, W. A. (1979) Distribution of the estimators for autoregressive time series with a unit root. Journal of the American Statistical Association, 74(336), p. 427-431.

Drake, L. (1995) Testing for convergence between UK regional house prices. Regional Studies, 29(4), p. 357-366.

Engle, R. F. and Granger, C. W. J. (1987) Co-integration and error correction: Representation, estimation, and testing. Econometrica, 55(2), p. 251-276. 
Granger, C. W. J. (1981) Some properties of time series data and use in econometric model specification. Journal of Econometrics, 16(1), p. 121130.

Granger, C. W. J. (1986) Development in the study of cointegrated economic variables. Oxford Bulletin of Economics and Statistics, 48, p. 213228.

Granger, C. W. J. and Newbold, P. (1974) Spurious regressions in econometrics. Journal of Econometrics, 2(2), p. 111-120.

Johansen, S. (1988) Statistical analysis of cointegration vector. Journal of Econometric Dynamics and Control, 12, p. 231-254.

MacDonald, R. and Taylor, M. P. (1993) Regional house prices in Britain: Long-run relationships and short-run dynamics. Scottish Journal of Political Economy, 40(1), p. 43-55.

Maher, C. (1994) Housing prices and geographical scale: Australian cities in the 1980s. Urban Studies, 31(1), p. 5-27.

Medhurst, D., Lea, J. and Pritchard, B. (2002) Housing assistance and regional disadvantage, In Australian Housing and Urban Research Institute (Ed, Australian Housing and Urban Research Institute), Sydney.

Meen, G. (1996) Spatial aggregation, spatial dependence and predictability in the UK housing market. Housing Studies, 11(3), p. 345-372.
Meen, G. (1999) Regional house prices and the ripple effect: A new interpretation. Housing Studies, 14(6), p. 733-753.

Phillips, P. C. B. and Perron, P. (1988) Testing for a unit root in time series regression. Biometrica, 75, p. 335-346.

Pollakowski, H. O. and Ray, T. S. (1997) Housing price diffusion patterns at different aggregation levels: An examination of housing market efficiency. Journal of Housing Research, 8(1), p. 107-124.

Sargan, J. D. (1984) Wages and prices in the United Kingdom: A study in econometric methodology, in Quantitative Economics and Econometric Analysis (Eds, Wallis, K. F. and Hendry, D. F.), Basil Blackwell, Oxford, UK.

Stevenson, S. (2004) House price diffusion and inter-regional and cross-border house price dynamics. Journal of Property Research, 21(4), p. 301-320.

Stock, J. H. and Watson, M. W. (1988) Testing for common trend. Journal of the American Statistical Association, 83(404), p. 1097-1107.

Tu, Y. (2000) Segmentation of Australia housing market: 1989-98. Journal of Property Research, 17(4), p. 311-327.

Yates, J. (2002) Housing implications of social, spatial and structural change. Housing Studies, 17(4), p. 581-618.

\section{SANTRAUKA}

\section{BŪSTO KAINŲ PASISKIRSTYMO STRUKTŪRA AUSTRALIJOS VALSTIJŲ SOSTINĖSE}

\section{Zhen Qiang LUO, Chunlu LIU, David PICKEN}

Neseniai mokslininkai nustatė, kad didmiesčiuose būsto kainos veikia vienos kitas (angl. ripple effect). Tačiau ši poveikị itin sunku suformuluoti ir išmatuoti pasitelkus ịprastas būsto kainų teorijas, ypač ịvertinant teritorinį miestų išsidèstymą. Remiantis ekonometrijos principais, tokiais kaip kointegracijos analizè ir klaidų taisymo modelis, šiame tyrime sukurtas novatoriškas būdas, kaip kiekybiškai tyrinèti būsto kainų pasiskirstymo struktūras šalies didmiesčiuose. Kaip pavyzdị pasirinkus aštuonias Australijos valstijų sostines, siūlomas būdas patvirtinamas empiriniu tyrimu. Rezultatai rodo, kad šių miestų pasiskirstymo struktūra yra 1-1-2-4. Sidnejjus užima aukščiausią pakopą, o Melburnas yra antrasis. Pertui ir Adelaidei tenka trečioji pakopa, o kiti keturi miestai yra žemiausiai. Šiuo tyrimu galima remtis prognozuojant regioninès būsto rinkos elgseną kitose šalyse. 
APPENDIX 1. Eight capital cities' error correction models of house price, based on Engle-Granger cointegration test

Adelaide

$\mathrm{D}($ Adelaide $)=0.592125 \mathrm{D}($ Brisbane $)-0.071363 \mathrm{ecm}_{t-1}$

$\mathrm{D}($ Adelaide $)=0.999985+0.523489 \mathrm{D}($ Canberra $)-0.121345 \mathrm{ecm}_{t-1}$

$\mathrm{D}($ Adelaide $)=1.880325+0.178691$ (Darwin $)+0.039621 \mathrm{ecm}_{t-1}$

$\mathrm{D}($ Adelaide $)=2.024509+0.146136 \mathrm{D}$ (Melbourne) $-0.066960 \mathrm{ecm}_{t-1}$

$\mathrm{D}($ Adelaide $)=0.843697 \mathrm{D}($ Perth $)+0.025933$ @ trend $-0.115226 \mathrm{ecm}_{t-1}$

\section{Brisbane}

$\mathrm{D}($ Brisbane $)=1.123505+0.92454 \mathrm{D}($ Adelaide $)-0.176697 \mathrm{ecm}_{t-1}$

$\mathrm{D}($ Brisbane $)=1.247305+0.785233 \mathrm{D}($ Canberra $)-0.165661 \mathrm{ecm}_{t-1}$

$\mathrm{D}($ Brisbane $)=2.016804+0.814583 \mathrm{D}($ Hobart $)+0.318391 \mathrm{ecm}_{t-1}$

$\mathrm{D}($ Brisbane $)=-0.074515+0.514525 \mathrm{D}($ Perth $)-0.084496 \mathrm{ecm}_{t-1}$

\section{Canberra}

$\mathrm{D}($ Canberra $)=0.831614+0.748329 \mathrm{D}($ Adelaide $)-0.114091 \mathrm{ecm}_{t-1}$

$\mathrm{D}($ Canberra $)=0.622968+0.590497 \mathrm{D}($ Brisbane $)+0.048743 \mathrm{ecm}_{t-1}$

$\mathrm{D}($ Canberra $)=1.998501+0.37917 \mathrm{D}($ Hobart $)-0.111247 \mathrm{ecm}_{t-1}$

\section{Darwin}

$\mathrm{D}($ Darwin $)=2.22478+0.387599 \mathrm{D}($ Perth $)-0.05735 \mathrm{ecm}_{t-1}$

\section{Hobart}

$\mathrm{D}($ Hobart $)=0.457519 \mathrm{D}$ (Adelaide) $-0.11915 \mathrm{ecm}_{t-1}$

$\mathrm{D}($ Hobart $)=0.353377 \mathrm{D}$ (Brisbane) $-0.155604 \mathrm{ecm}_{t-1}$

$\mathrm{D}($ Hobart $)=1.098697+0.172205 \mathrm{D}($ Canberra $)-0.226244 \mathrm{ecm}_{t-1}$

$\mathrm{D}($ Hobart $)=0.59952 \mathrm{D}($ Perth $)-0.13201 \mathrm{ecm}_{t-1}$

\section{Melbourne}

$\mathrm{D}($ Melbourne $)=0.316987 \mathrm{D}($ Adelaide $)+0.05001 \mathrm{ecm}_{t-1}$

$\mathrm{D}($ Melbourne $)=0.077697 \mathrm{D}($ Brisbane $) 0.067012 @$ trend $+0.005289 \mathrm{ecm}_{t-1}$

$\mathrm{D}($ Melbourne $)=1.226928+0.452196 \mathrm{D}($ Perth $)+0.081181 \mathrm{ecm}_{t-1}$

$\mathrm{D}($ Melbourne $)=0.859187+0.523499 \mathrm{D}($ Sydney $)-0.288406 \mathrm{ecm}_{t-1}$ 


\section{Perth}

$\mathrm{D}($ Perth $)=-1.13736+0.228256 \mathrm{D}$ (Adelaide) +0.081339 @ trend -0.217385 ecm $_{t-1}$

$\mathrm{D}($ Perth $)=-1.922126+0.197337 \mathrm{D}($ Brisbane $)+0.103375$ @ trend -0.071376 ecm $_{t-1}$

$\mathrm{D}($ Perth $)=0.135804 \mathrm{D}$ (Hobart) $-0.035618 \mathrm{D}($ Hobart(-1))+0,982327D(Perth(-1))-0.630636 ecm t-1

$\mathrm{D}($ Perth $)=0.337008 \mathrm{D}($ Melbourne $)-0.053628$ ecm $_{t-1}$

\section{Sydney}

$\mathrm{D}($ Sydney $)=0.301322 \mathrm{D}($ Darwin $)+0.011978$ ecm $_{t-1}$

$\mathrm{D}($ Sydney $)=2.170157+0.247951 \mathrm{D}($ Melbourne $)-0.275755 \mathrm{ecm}_{t-1}$

$\mathrm{D}($ Sydney $)=-0.367108-0.296417 \mathrm{D}($ Perth $)+0.108104$ @ trend +0.191727 ecm $_{t-1}$

$\mathrm{D}($ Sydney $)=0.278044 \mathrm{D}($ Hobart $)+0.068322$ @ trend +0.050946 ecm $_{t-1}$

Notes:

1. The development and derivation of these equations is described in Section 2.

2. The error correction model is made as

$$
\Delta Y_{t}=\beta_{0}+\beta_{1} \Delta X_{t}-\lambda e c m_{t-1}+\mu_{t}
$$

where: $\Delta Y_{t}$ and $\Delta X_{t}$ denotes time series $Y_{t}$ and $X_{t}$ at first difference level respectively; $Y_{t}$ and $X_{t}$ are assumed to be integrated at first difference in this model; The symbol of $e c m_{t-1}$ is the error correction term and $e c m_{t-1}=$ $\left(Y_{t-1}-\alpha_{1}-\alpha_{2} X_{t-1}\right)$.

3. The symbol of' @ trend'denotes a deterministic trend.

4. All equations derive from Table 4. 